\title{
Urban Trees Programs from Municipal Officials' Perspective: Evidence from Alabama, U.S.
}

\author{
Yaoqi Zhang and Bin Zheng
}

\begin{abstract}
Using survey data, this study explored Alabama municipal employees and policy makers' perception of urban trees, financing, governing, and information sharing regarding urban forest management. Results suggest that the importance of urban trees is widely recognized by local municipal employees and policymakers. They also believe that urban trees would increase property value and promote community pride. Ecological benefits were, however, less valued. Alabama, U.S. cities spent less than USD $\$ 60,000$ per year on tree planting, tree maintenance, debris, and tree removal. Cities with a large population usually appear to spend more on urban trees; likewise, cities with higher household incomes and lower poverty rates would have higher expenditures on urban tree programs. Relatively minor differences were found among the three types of employees and administrators: mayors, council members, and administrators. The results indicate many municipal officials were not aware of, or informed about, related agencies providing urban tree management services.

Key Words. Environmental Awareness; Municipal; Perceptions; Public Infrastructure; Regional Development; Survey; Urban Planning.
\end{abstract}

To promote and support urban tree programs, it is important to have the support of various local employees and policymakers, including the mayor, city council members, and other administrators. Not all local administrators and employees, however, have the same understanding about the costs/problems (e.g., management costs, medical costs associated with allergies, damage to property or personal safety) and benefits (e.g., improvement in air quality, reduction in stormwater runoff, decrease in energy costs) of trees, and they might have various perceptions.

Human understanding and perception of its surroundings depends to a large extent on knowledge and experience. Large differences in knowledge of program benefits and costs could explain why perceptions vary, and why some municipal employees are more inclined than others to value urban tree programs. As such, it is important to know how much information is available to them about urban trees, the costs and benefits associated with them, and what kind of information is needed. Given limited resources at their disposal, it is not possible to invest in all kind of information programs without assessing the demand for them and the available supply.

The objectives of this study were threefold: 1) assess local officials' perception of urban trees and urban forest management in Alabama, U.S., and determine if there are differences in the attitudes of the three types of officials (mayor, council member, administrator) toward them; 2) analyze the influential factors of the budget on urban tree programs; and 3) explore municipal officials' awareness of the governing and sharing of information regarding urban tree management. The researchers were particularly interested in what might affect the amount of money the respondent's community spent on the trees in the following four categories: urban tree planting, urban tree maintenance, urban tree debris removal, and urban tree removal.

To assess the perception and support of municipal employees, administrators, and policymakers to urban forestry development in the state of Alabama, this paper summarizes how they perceive the role of urban trees, how the funding of urban tree programs is distributed, how they are getting and sharing forestry service information, and what information is demanded.

\section{LITERATURE REVIEW}

Considering the importance of public involvement in urban tree programs for positive changes in the community (Relf 1992), many studies have been conducted on the public attitudes and perceptions of urban tree programs (e.g., Summit and McPherson 1998; Wolf 2003; Treiman and Gartner 2005; Zhang et al. 2007; Stevenson et al. 2008). Treiman and Gartner (2005) found that most community officials are interested in tree preservation. Mayors, council members, and public works administrators also play an important role in organizing and implementing municipal tree planting and help to regulate the coordination among agencies and groups (Dwyer et al. 2003; Pincetl 2010).

Green et al. (1998) and Schroeder et al. (2003) conducted surveys in Illinois, U.S., independently and showed that local municipal officials have strong positive attitudes toward community trees regardless of the community's size. Allen (1995) also reported that municipal employees in Missouri, U.S., had a positive attitude toward urban forestry regardless of region, population class, metropolitan or rural community, or Tree City USA status. It was found that tree activists, the chamber of com- 
merce, municipal officials, and elected officials shared similar opinions on urban tree and forest management (Ricard 1994).

Stevenson et al. (2008) collected survey responses from 528 officials in 356 municipalities regarding the developmental status of municipal street tree programs. Three types of officials were asked to complete surveys: elected chief officials, public works administrators, and municipal solicitors. They found that in existing programs, which had an ordinance, tree commission, inventory, and management plan, officials had more positive attitudes about trees than in developing programs. However, even for cities without existing programs (or with the intention to develop them), half of the officials believed that benefits of street trees outweigh the costs and problems.

Many aspects of municipal officials' attitude toward urban trees and management have not been explored in past studies. Mostly, only the positive or benefits were assessed, not the cost or problems. It has not been investigated how the knowledge on urban trees of the employees and administrators would have an impact on the city's budget allocation toward urban forestry. It is also not clear whether there are any variations among the different officials regarding their perceptions of urban tree programs. This study aims to contribute to the literature from these aspects.

\section{DATA AND METHODS}

This paper uses data from a survey of Alabama urban forestry in 2003. The survey reached cities having more than 250 residents. The respondents included municipal clerks, administrators, and mayors. For cities with more than 1,500 residents, the council members were also surveyed. The respondents selected in each municipality represent those who could potentially influence the start or improvement of a tree program. The survey contacted 1,862 persons who worked for city administrative offices, of which $797(43 \%)$ responded from 336 cities. Responses from the secretaries of city offices, mayors, council members, and other city administrators were 12,204, 359 , and 220, respectively. Among the respondents, $33.12 \%$ were from municipalities with a population less than 2,000; $23.46 \%$ were from a population ranging between 2,001 and 5,$000 ; 18.32 \%$ were from a population ranging between 5,001 and 10,000; and $25.07 \%$ were from a population of over 10,000 .

The survey included questions regarding following aspects: a) the level of importance of urban trees to community citizens; b) levels of problems from urban forests; c) benefits and problems of urban forests; d) opportunities offered by the community for its citizens to be involved (e.g., volunteer and donate money) in urban forestry; and e) awareness of community funding for urban forests and their changes.

The respondents were requested to indicate their awareness of the existence of tree agencies or programs, which may include a Tree Board, Tree Commission, City Forester, Municipal tree program, Privately funded tree program, publicly funded tree program, Citizen Advocacy Group, Tree inventory, Street tree ordinance, Landscape ordinance, Tree protection ordinance, Nuisance tree ordinance, Park/public tree ordinance, View ordinance, Urban Forestry Department, or Ordinance governing trees on private properties. The respondents were also inquired regarding their familiarity with a service/agency or program of urban trees at the state level. Examples include the U.S. Department of Agriculture Forest Service, National Arbor Day Foundation, American Forests, International Society of Arboriculture, Alabama Forestry Commission, Tree for Alabama, and Alabama Urban Forestry Association.

Regression analysis, more specifically, the Ordinary Least Squares (OLS) models, were used to assess what might affect the amount of money the respondents' community spent on the trees in the following four categories: urban tree planting, urban tree maintenance, urban tree debris removal, and urban tree removal. It is hypothesized that the amount of money spent on each management category is a function of a city/community's characteristics and the attitude of municipal officials toward trees. The amount of funding cities can provide is highly related to their socioeconomic status, such as household income, poverty rate, race composition, and education level. It was believed that the municipal employees' attitudes toward urban trees and their knowledge of urban tree programs could be important. Models are presented below:

$$
\log \left(\mathrm{Y}_{1}^{\mathrm{j}}\right)=\beta_{0}+\beta_{i} x_{i}+\varepsilon
$$

where $\mathrm{j}=1, \ldots, 4$, representing the four categories of urban tree funding uses (see Table 1). The explanation of dependent variables $\mathrm{Y}$ and independent variables $\mathrm{X}_{\mathrm{i}}$ are shown in Table 1. The values of $\mathrm{X} 1$ to $\mathrm{X} 5$ were obtained from U.S census survey data in 2000 through a zip code inquiry. The values of $\mathrm{X} 6$ to $\mathrm{X} 9$ were constructed from the survey questions. The descriptive statistics were also shown in Table 1.

Table 1. Description of explanatory variables used in the analysis. Currency is expressed in U.S. dollars.

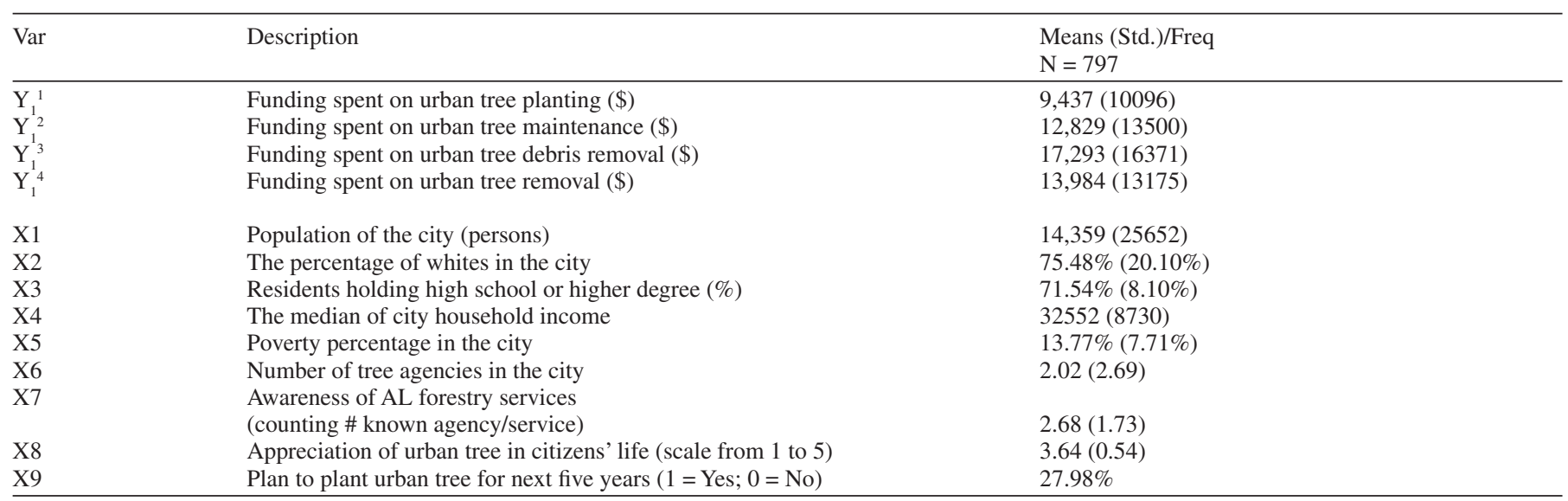


RESULTS

\section{Perceptions of Cost and Benefit}

The attitudes and perceptions of respondents can be expected to influence their actions toward starting or improving city tree programs. The role of urban forestry was recognized by them in Alabama (see Table 2). A four-point Likert scale measured the importance level of these elements, extending from 4 (very important) or 3 (somewhat important), to 1 (not at all important). The overall average rating for the importance of trees in the community and trees to citizens were 3.88 and 3.64, respectively. A further ANOVA test suggested that there was no statistically significant difference between any of two groups for mayor, council member, and administrator. Thus, in general, the important role of trees for residents and the community was highly recognized by all municipal officials.

The most favored tree benefits recognized by local officials are shown in Table 3. In general, the top three favorite benefits were: an increase in community pride $(40 \%-46 \%)$, an increase in prop- erty value $(35 \%-45 \%)$, and an increase in recreational opportunities $(39 \%-41 \%)$. It seemed that the three types of officials had a similar preference for the most favored benefits. The only differences that appear among them were in regard to the ecological benefits and health issues, such as "decrease in soil erosion," "improvement in water quality," and "creation of buffer zones." These differences in the perceptions of tree benefits indicate that knowledge of their tree programs may be incomplete or not fully understood.

Regarding the attitudes toward municipal tree management practices, the results in Table 2 suggest that tree pruning, tree preservation, and tree ordinances are the most popular services in urban tree management. Considering the cost, local officials chose the top two costs/ problems as: irrigation costs $(58 \%-66 \%)$ and insect \& disease control $(47 \%-57 \%)$ (Table 3). Three types of officials seemed to have different concerns regarding these costs/problems. Mayors paid relatively more attention to the cost of tree maintenance (e.g., planting, pruning) and paid relatively less attention to the cost of administering a local urban tree program. In contrast, local administrators were more concerned about administration costs rather than tree maintenance costs.

Table 2. Perception of public officials about the role of urban trees and tree management

\begin{tabular}{|c|c|c|c|c|}
\hline & Mayor & Council member & Administrator & Overall rating \\
\hline & & \multicolumn{3}{|l|}{ Mean (std. dev) } \\
\hline & \multicolumn{4}{|l|}{ The presence of urban trees } \\
\hline Trees to community & $3.89(0.36)$ & $3.91(0.31)$ & $3.83(0.42)$ & $3.88(0.36)$ \\
\hline Trees to the citizens & $3.68(0.52)$ & $3.63(0.54)$ & $3.61(0.53)$ & $3.64(0.53)$ \\
\hline & \multicolumn{4}{|l|}{ Tree management practice } \\
\hline Tree topping ${ }^{z}$ & $2.45(1.00)$ & $2.71(0.98)$ & $2.51(0.98)$ & $2.59(0.99)$ \\
\hline Tree pruning & $3.53(0.73)$ & $3.60(0.69)$ & $3.53(0.76)$ & $3.56(0.72)$ \\
\hline Tree preservation $^{\mathrm{z}}$ & $3.45(0.68)$ & $3.50(0.65)$ & $3.60(0.59)$ & $3.51(0.64)$ \\
\hline Tree ordinances ${ }^{z}$ & $3.07(0.90)$ & $3.23(0.87)$ & $3.14(0.84)$ & $3.16(0.87)$ \\
\hline Choice regulation & $1.85(0.95)$ & $1.94(0.96)$ & $1.83(0.88)$ & $1.88(0.94)$ \\
\hline Use of tax for tree program & $2.83(0.94)$ & $2.81(0.90)$ & $2.73(0.95)$ & $2.79(0.92)$ \\
\hline
\end{tabular}

${ }^{\mathrm{z}}$ A significant difference exists between at least two groups of the mayor, council member, and administrator.

Table 3. Alabama officials (mayor, council member, administrator) perceptions of benefits and problems of urban trees.

\begin{tabular}{|c|c|c|c|}
\hline & $\begin{array}{l}\text { Mayor } \\
\mathrm{N}=204\end{array}$ & $\begin{array}{l}\text { Council member } \\
\mathrm{N}=359\end{array}$ & $\begin{array}{l}\text { Administrator } \\
\mathrm{N}=220\end{array}$ \\
\hline & & \multicolumn{2}{|l|}{ Benefits } \\
\hline Increase in property values $^{2}$ & $45 \%$ & $45 \%$ & $35 \%$ \\
\hline Decrease in energy costs & $25 \%$ & $24 \%$ & $19 \%$ \\
\hline Improvement in air quality & $31 \%$ & $29 \%$ & $33 \%$ \\
\hline Reduction of noise levels & $18 \%$ & $13 \%$ & $11 \%$ \\
\hline Decrease in soil erosion ${ }^{2}$ & $23 \%$ & $34 \%$ & $25 \%$ \\
\hline Improvement in water quality ${ }^{\mathrm{z}}$ & $26 \%$ & $24 \%$ & $32 \%$ \\
\hline Creation of wildlife habitat & $28 \%$ & $34 \%$ & $35 \%$ \\
\hline Increase in community pride & $46 \%$ & $40 \%$ & $41 \%$ \\
\hline Reduction in storm water runoff & $15 \%$ & $17 \%$ & $20 \%$ \\
\hline Increase in recreational opportunities & $39 \%$ & $41 \%$ & $40 \%$ \\
\hline Improvement in health and well-being ${ }^{z}$ & $9 \%$ & $4 \%$ & $3 \%$ \\
\hline Positive impact on consumer behavior & $15 \%$ & $16 \%$ & $11 \%$ \\
\hline \multirow[t]{2}{*}{ Creation of buffer zones ${ }^{z}$} & $9 \%$ & $6 \%$ & $3 \%$ \\
\hline & & \multicolumn{2}{|c|}{ Problems and Costs } \\
\hline Irrigation costs ${ }^{\mathrm{z}}$ & $61 \%$ & $66 \%$ & $\mathbf{5 8 \%}$ \\
\hline Recycling pruned tree $\operatorname{limb}^{2}$ & $24 \%$ & $29 \%$ & $32 \%$ \\
\hline Removing hazardous trees & $31 \%$ & $30 \%$ & $28 \%$ \\
\hline Insect and disease control ${ }^{\mathrm{z}}$ & $\mathbf{5 7 \%}$ & $47 \%$ & $55 \%$ \\
\hline $\begin{array}{l}\text { Root damage to sidewalks, curbs, } \\
\text { and utility lines }\end{array}$ & $7 \%$ & $9 \%$ & $8 \%$ \\
\hline Medical costs associated with allergies & $7 \%$ & $10 \%$ & $7 \%$ \\
\hline Administering a local urban tree program ${ }^{2}$ & $14 \%$ & $25 \%$ & $30 \%$ \\
\hline Damage to property or personal safety & $29 \%$ & $35 \%$ & $37 \%$ \\
\hline
\end{tabular}

${ }^{\mathrm{z}}$ A significant difference exists between at least two groups of the mayor, council member, and administrator. 


\section{Governing and Information Sharing}

Tree governing and serving agencies are important in urban tree management. The survey findings, presented in Figure 1, suggested that the most popular tree governing agencies in cities among the municipal officials were any "municipal tree program," "tree board," and "citizen advocacy group." Around 24\% of the cities had a municipal tree program. Moreover, findings indicated that the percentage of cities having a privately funded tree program (16\%) was higher than publicly funded tree program (10\%).

As evidenced in Table 4, there were $72 \%-82 \%$ of respondents knew of American Forests. The Auburn University School of Forestry and Wildlife Science (Auburn, Alabama, U.S.) was also one of the main information sources for local municipal offices. However, other agencies such as Tree for Alabama, the International Society of Arboriculture, and Alabama Forestry Commission were also important but received a low recognition. Comparing the three types of city officials, the results indicated mayors were better informed about services from various agencies, followed by council members. The percentage of the officials who are familiar with those agencies was the lowest.

A full understanding of urban tree programs can help municipal officials to better manage and allocate the government's resources for their citizens. There is a demand for urban tree information by municipal officials, not only about the biophysical maintenance and management, but also the socioeconomic concerns. The information most desired by local officials was the cost of urban forestry $(65 \%-76 \%)$, followed by the tree pest management $(60 \%-73 \%)$. Tree selection and volunteer training information was also needed. Municipal officials were more concerned about the economic cost of urban trees management

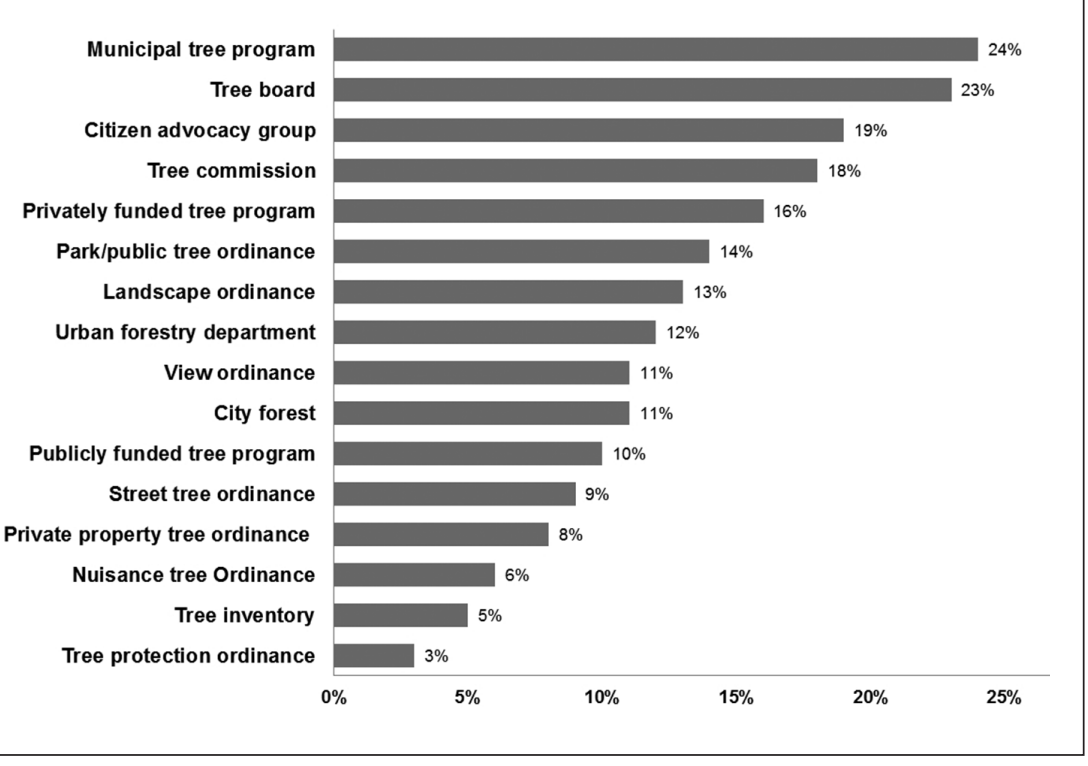

Figure 1. Presence of urban tree programs and their related agencies.

and how to better manage and maintain the existing trees. Less concern was put toward tree planting (22\%-28\%) (Table 5).

Timely news and updated information regarding urban trees and urban forestry are very important for municipal official decision making, especially regarding funding availability. The findings represented in Figure 2 suggest that mail was the preferred way to receive urban forestry information (79\%), compared to e-mail $(49 \%)$. Paper mailings were more official and reliable for municipal officials. The internet provides a large amount of information and it is easily accessed. Around $67 \%$ of the local officials preferred receiving information via internet. Having classes or seminars offered on topics related to urban tree care was recognized as an effective way to gain knowledge of urban trees (63\%). Meeting with forestry professionals directly was also a good choice.

Table 4. Alabama officials (mayor, council member, administrator) awareness about urban trees-related agencies and additional information needs.

\begin{tabular}{|c|c|c|c|}
\hline & $\begin{array}{l}\text { Mayor } \\
\mathrm{N}=204\end{array}$ & $\begin{array}{l}\text { Council member } \\
\mathrm{N}=359\end{array}$ & $\begin{array}{l}\text { Administrator } \\
\mathrm{N}=220\end{array}$ \\
\hline & & \multicolumn{2}{|c|}{ Information known } \\
\hline USDA Forest Service ${ }^{\mathrm{z}}$ & $60 \%$ & $52 \%$ & $40 \%$ \\
\hline Tree for Alabama ${ }^{\mathrm{z}}$ & $10 \%$ & $6 \%$ & $5 \%$ \\
\hline American Forest ${ }^{\mathrm{z}}$ & $82 \%$ & $72 \%$ & $74 \%$ \\
\hline International Society of Arboriculture ${ }^{\mathrm{z}}$ & $13 \%$ & $8 \%$ & $5 \%$ \\
\hline Alabama Urban Forestry Association ${ }^{z}$ & $34 \%$ & $24 \%$ & $25 \%$ \\
\hline AU Sch. of Forestry and Wildlife Sci. & $73 \%$ & $66 \%$ & $67 \%$ \\
\hline Alabama Forestry Commission & $5 \%$ & $3 \%$ & $3 \%$ \\
\hline \multirow[t]{2}{*}{ National Arbor Day Foundation ${ }^{2}$} & $27 \%$ & $32 \%$ & $17 \%$ \\
\hline & & \multicolumn{2}{|c|}{ Information want to know } \\
\hline Urban tree benefits ${ }^{2}$ & $42 \%$ & $43 \%$ & $30 \%$ \\
\hline Urban forestry costs ${ }^{z}$ & $70 \%$ & $76 \%$ & $65 \%$ \\
\hline Tree selection & $49 \%$ & $58 \%$ & $54 \%$ \\
\hline Tree planting & $28 \%$ & $28 \%$ & $22 \%$ \\
\hline Young tree care & $43 \%$ & $50 \%$ & $46 \%$ \\
\hline Volunteer training & $48 \%$ & $50 \%$ & $45 \%$ \\
\hline
\end{tabular}

${ }^{\mathrm{z}}$ A significant difference exists between at least two groups of the mayor, council member, and administrator. 
Table 5. Ordinary Least Squares Regression (OLS) results about funding urban tree program.

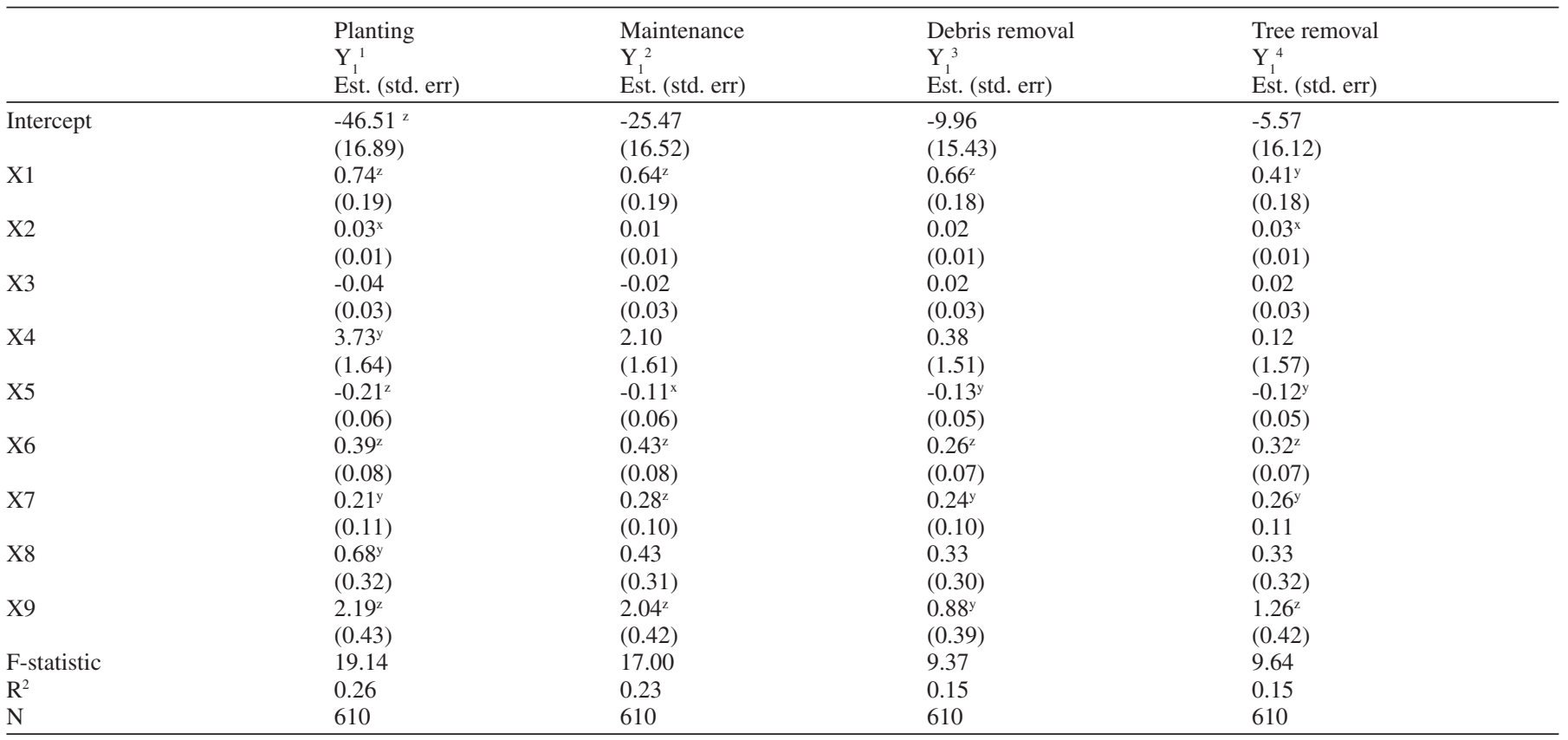

${ }^{2}$ Indicates a significance level of 0.001 .

${ }^{y}$ Indicates a significance level of 0.05 .

${ }^{x}$ Indicates a significance level of 0.01 .

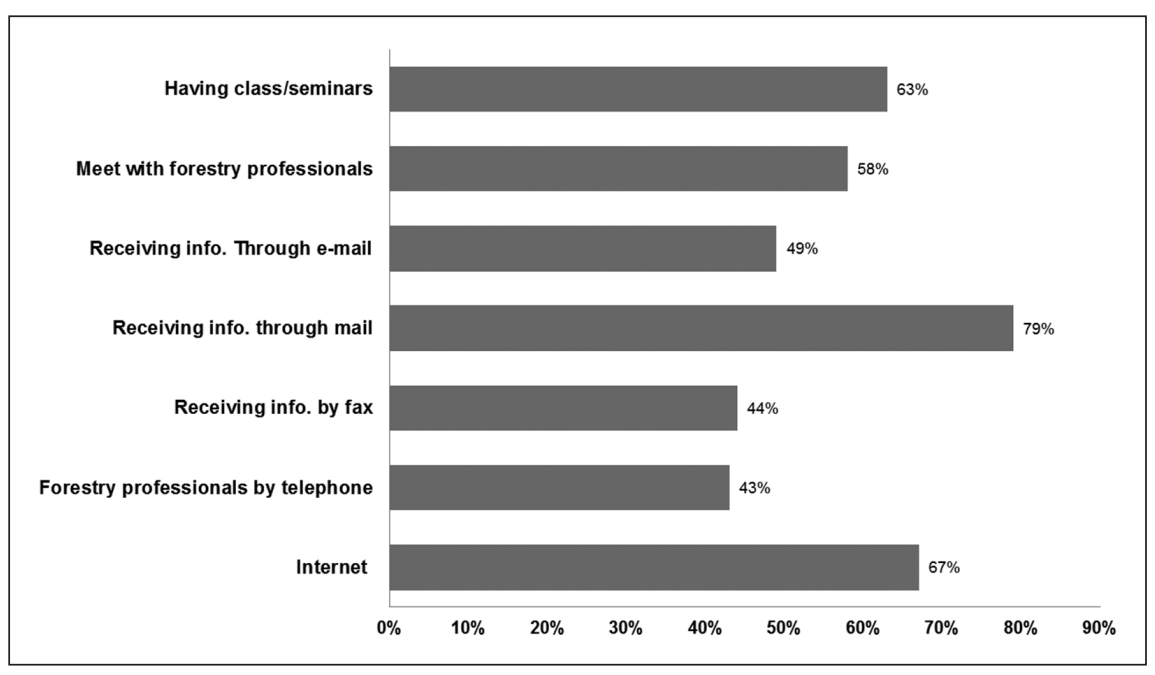

Figure 2. Effective ways to provide information about urban trees.

\section{Support of Urban Tree Programs}

Financial support is the most effective way to promote urban tree and urban forestry programs. Planting and maintaining trees in city requires significant input of money and labor (Kielbaso 1990). Lack of funding is also the most important barrier to starting or improving tree programs (Grado et al. 2006; Stevenson et al. 2008). Regarding the budget on urban forestry, most Alabama cities spent less than USD \$20,000/ year for each category of tree management (Table 1). On average, funding for tree debris removal was the most $(\$ 17,293)$.

The regression results on what might affect spending are reported in Table 5. The log form was used for the dependent variable of amount of funding on each model as well as the independent variables of population (X1) and household income (X4). In this way, the estimates of coefficient represent elasticity, measuring the percentage change of the dependent variable in response to percentage changes of independent variables. Four models were all statistically significant at a 0.01 level. $\mathrm{R}^{2}$ ranged from 0.15 to 0.26 .

The population of the city (X1) was statistically significant in four models at a 0.05 level, suggesting population as an important predicator for funding allocation of the city. The funding used for tree planting will increase by $0.74 \%$, while the city population increases by $1 \%$. The population-funding elasticity was less than 1 for all of the four categories, suggesting an inelastic effect to the amount of funding.

The percentage of Caucasian individuals in the city (X2) was significant at a 0.01 statistic level in the first and fourth model, suggesting the percentage of Caucasians in a city or community had a slight but positive effect on the funding of tree planting and tree removal. X3 was not statistically significant in any of these models, suggesting the percentage of high school graduates in the city had no significant impact on tree program funding allocation.

Household income (X4) was significant and positively related to funding for a tree planting. The elasticity of 3.74 implied the income effect was very elastic. Although Alabama cities usually had a relatively low input in urban trees, one can still see a large potential for tree planting plan in the future for many cities. With a better economic situation, the funding allocated toward tree planting would be increased. Specifically, when household income increases by $1 \%$, the funding for tree planting will increase by $3.73 \%$. 
Poverty rate (X5) had significant negative effect on funding for tree programs. A high poverty rate in the city or community will reduce the funding of urban tree programs. So in a relatively poor city, financing for tree planting will mostly be cut in urban tree programs.

The number of tree agencies in cities (X6) and the awareness of Alabama forestry service (X7) both had a positive contribution to tree program financing. The magnitude of the effect of X6 on tree maintenance was the largest compared to the other three categories (0.43). That is to say, the funding for tree maintenance will benefit from the increased awareness of tree agencies. Also, the awareness of forestry services will help tree maintenance by a large amount $(0.28)$. Other urban tree service financing, such as debris and tree removal, will also be beneficial from the promotion of tree agencies and services.

Whether a city has plans to plant more trees within the next five years (X9) can significantly influence the financing of an urban tree program. Cities with tree planting plans will increase the tree planting funding by exp (2.19); tree maintenance funding by exp (2.04), debris removal funding by exp (0.88), and tree removal funding by exp (1.26), comparing to cities without tree planting plans. This is reasonable because if the city would plant more trees in the future, the spending on tree planting will definitely be increased. More funding will be needed to manage and maintain the newly planted trees as well. Local officials' preference toward trees was not statistically significant in most of the models. The municipal officials' appreciation of urban trees in citizens' lives (X8) was only significantly related to tree planting funding. How much they love trees or consider trees to be important in citizens' lives seemed unrelated to the real spending on tree programs.

The opportunity for citizens to support urban trees in either voluntary or donation forms was also a very important part for supporting urban tree programs. The survey results found that almost half of the cities offered opportunities for its citizens to volunteer to plant trees (Figure 3). For the maintenance of urban trees and removal of debris from the disposal of urban trees, the percentages were $39 \%$ and $43 \%$, respectively. As for the opportunity for citizens to donate money to support urban tree programs, the percentages were relatively low. For planting trees, $43 \%$ of the Alabama cities provided ways for their citizens to donate. For maintenance of urban trees and removal of

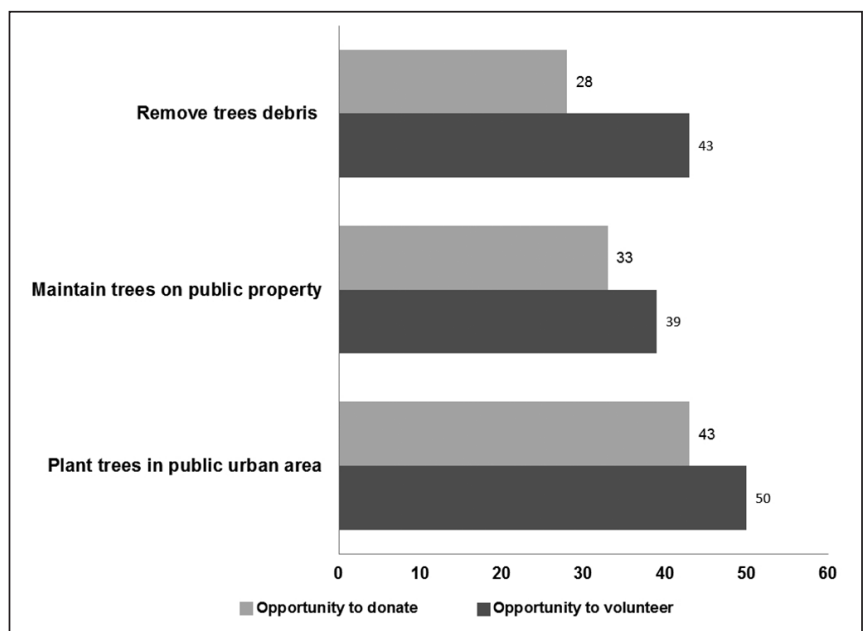

Figure 3. Information on citizens' willingness to contribute to urban tree programs. debris from the disposal of urban trees, the percentages were only $33 \%$ and $28 \%$, respectively. Thus, less than half of cities provided their citizens with ways to donate. More efforts can be made.

\section{CONCLUSIONS AND DISCUSSIONS}

The findings indicate that the significance of urban forestry is widely recognized by Alabama local officials. Most local officials considered urban trees in the community to be very important. Zhang et al. (2007) found that $77 \%$ of citizens consider trees to be important in selecting a residence. So both citizens and local officials like trees in general. However, municipal officials are responsible for allocating funding and managing public trees, and so their concerns about trees are different from residents. As for the benefits of trees, it seemed that municipal officials paid more attention to the socioeconomic benefit of trees (such as increased property value and an increase in community pride) than in trees' ecological values. Residents in communities usually favored the aesthetical and health value (Lewis 1992; Thompson et al. 1999), and the residents' awareness of economic benefits was very low (Jim and Chen 2006). Municipal officials want to have more information about urban forestry management cost, while residents usually want to know more about tree care in their own yard (Zhang et al. 2007).

More importantly, the ecological benefits were considered less significant by municipal officials. The benefit of improved of health and well-being was least valued. The difference in tree benefit perception among the three types of officials is an indication that knowledge about their tree programs may be incomplete or not fully understood. This incomplete understanding of the benefits of trees and tree care practices may lead to low public support, insufficient funding, and inadequate personnel and equipment. Meanwhile, it seems that local municipal officials do not know the financial situation of their community's urban forestry program very well. This finding indicates that around $20 \%-30 \%$ of the municipal officials did not know how much money was spent in their community on urban tree programs. Stevenson et al. (2008) found that only $20 \%-42 \%$ of the officials regarded a well-funded tree program to be as important as other municipal responsibilities. Many were unaware of available grants or technical assistance. Thus, more education opportunities should be provided. Officials may be persuaded to start or improve tree programs by explaining benefits more fully, and how public safety can be improved by proper pruning, inventories that locate dangerous trees, and management plans that arrange to remove them.

When compared to the importance of planting trees, local municipal officials were more concerned about how to manage and maintain existing trees. More money had been spent on tree maintenance (e.g., tree debris removal) rather than tree planting. In an Illinois community survey, spending municipal funds on the removal of hazardous trees received the greatest support from municipal officials and foresters (Schroeder et al. 2003). Research has shown that adequate funding for tree programs can be achieved where officials perceive that residents are supportive (Robeson 1984; Elmendorf et al. 2003). In the present study, municipal officials expressed high appreciations for trees. However, actual spending on tree programs was highly influenced by the economic situation facing a community. The findings indicate that appreciation for trees had 
no significant impact on the financing of urban tree programs. The fact that demand for urban trees is high does not mean the local officials will spend more on urban tree programs. The cost of urban trees and their affordability are primary concerns for the municipal officials. This suggests that social economic factors, such as percentage of Caucasian citizens, household income level, and the poverty rate were significant predictors, which is consistent with Zhu and Zhang (2006) and Zhu and Zhang (2008), which reported positive impacts of economic development on support for urban trees.

Furthermore, providing citizens with the opportunity to be active in promoting community trees is an important part of management. Funding might also be alleviated by using volunteers, grants, and available technical advice. Voluntary activities and personal donations provide important support for urban tree programs, especially when funding is limited. Findings suggested that about half of the cities offered opportunities for their citizens to volunteer in order to provide support for urban trees in their community, but less than half of cities provided the opportunity for donation. Further, based on these findings, the percentage of privately funded urban tree programs was higher than publicly funded ones. Individual donation is a very important source for financing urban tree programs. More efforts can be made.

The regression results revealed that large cities usually provided more opportunities for citizens to support tree programs. Community involvement in management is prevalent (Stenhouse 2004). Large cities usually have more tree agencies and accessible forest services, which can provide more opportunities for citizens to be involved in urban forestry, not only as a volunteer but also with a monetary donation. Tree agencies also played an important role in getting funding/donations from government, businesses, or individual persons. Alabama forestry services provided reliable source of information and technical support for urban trees. Together they provided the public with comprehensive information and service about trees. Better understanding and effective use of tree agency and forestry services will also help to finance urban tree programs, including tree planting, maintenance, and debris and tree removal.

Mayors had relatively more knowledge about Alabama forest service. They were relatively more concerned about tree planting and maintenance costs than were council members and administrators. However, relatively minor differences were found among the three types of officials in regards to their preferences of trees' benefits and disadvantages. This result was consistent with findings from Ricard (1994) and Stevenson et al. (2008).

A good understanding of the benefits of urban trees and an awareness of available forestry services will help to promote urban tree programs. Municipal officials should be provided with more chances to get specific training or education opportunities in their work. Mail and internet are important ways to get information. Having classes or seminars offered on topics related to urban tree care is also an effective way to spread knowledge about urban trees. Support from forestry professionals in the Alabama forestry service is also recommended as a good option.

\section{LITERATURE CITED}

Allen, L. 1995. A social, economic, and political analysis of Missouri's urban forest. University of Missouri, Columbia, Missouri, U.S. 135 pp.

Dwyer, J.F., D.J. Nowak, and M.H. Noble. 2003. Sustaining urban forests. Journal of Arboriculture 29(1):49-55.

Elmendorf, W.F., V.J. Cotrone, and J.T. Mullen. 2003. Trends in urban forestry practices, programs and sustainability: Contrasting a Pennsylvania, U.S. study. Journal of Arboriculture 29:237-247.

Grado, S.C., D.L.,Grebner, M.K., Measells, and A.L. Husak. 2006. Status, needs, and knowledge levels of Mississippi's communities relative to urban forestry. Arboriculture \& Urban Forestry 32:24-31.

Green, T.L., T.J., Howe, and H.W. Schroeder. 1998. Illinois Small Community Tree Programs: Attitudes, Status, and Need. Western Illinois University, Macomb, Illinois, U.S. 124 pp.

Jim, C.Y., and W.Y. Chen. 2006. Perception and attitude of residents toward urban green spaces in Guangzhou (China). Environmental Management 38(3):338-349.

Kielbaso, J. 1990. Trends and issues in city forests. Journal of Arboriculture 16(3):69-76.

Lewis, C.A. 1992. Effects of plants and gardening in creating interpersonal and community well-being. In: D. Relf (Ed.). The Role of Horticulture in Human Well-Being and Social Development: A National Symposium. Timber Press, Portland, Oregon, U.S.

Pincetl, S. 2010. Implementing municipal tree planting: Los Angeles million-tree initiative. Environmental Management 45:227-238.

Relf, D. 1992. Human issues in horticulture. HortTechnology 2(2): $159-171$.

Ricard, R.M. 1994. Urban and community forestry survey results. University of Connecticut Cooperative Extension System, Haddam, Connecticut, U.S. 54 pp.

Robeson, H.L. 1984. Urban forestry in the Chicago suburbs. Journal of Arboriculture 10:113-116.

Schroder, H.W., T.L., Green, and T.J. Howe. 2003. Community tree programs in Illinois, U.S.: A statewide survey and assessment. Journal of Arboriculture 29(4):218-225.

Stenhouse, R.N. 2004. Local government conservation and management of native vegetation in urban Australia. Environmental Management 34(2):209-222.

Stevenson, T.R., H.D. Gerhold, and W.F. Elmendorf. 2008. Attitudes of municipal officials toward street tree programs in Pennsylvania, U.S. Arboriculture \& Urban Forestry 34(3):144-151.

Summit, J., and E.G. McPherson. 1998. Residential tree planting and care: A study of attitudes and behavior in Sacramento, California. Journal of Arboriculture 22(2):89-97.

Thompson, R., R. Hanna, J. Noel, and D. Piirto. 1999. Valuation of trees aesthetics on small urban-interface properties. Journal of Arboriculture 25(5):225-233.

Treiman, T., and J. Gartner. 2005. What do people want from their community forests? Results of public attitude survey in Missouri, U.S. Journal of Arboriculture 31(5):243-250.

Wolf, K.L. 2003. Public responses to the urban forest in inner-city business districts. Journal of Arboriculture 29(3):117-126.

Zhang, Y., A. Hussian, J. Deng, and N. Letson. 2007. Public Attitudes towards urban trees and supporting urban tree programs. Environment and Behavior 39(6):797-814

Zhu, P., and Y. Zhang. 2006. Demand for urban forests and economic welfare: evidence from the Southeastern U.S. Cities. Journal of Agricultural and Applied Economics 38(2):279-285

Zhu, P., and Y. Zhang. 2008. Demand for urban forests in United States cities. Landscape and Urban Planning 84:293-300. 
Yaoqi Zhang (corresponding author)

Auburn University

Forestry and Wildlife Sciences

Auburn, Alabama, U.S.

Bin Zheng

Auburn University

Forestry and Wildlife Sciences

Auburn, Alabama, U.S.

Zusammenfassung. Auf der Basis von erhobenen Daten aus Umfragen, untersucht diese Studie die Wahrnehmung von Stadtbäumen durch Stadtangestellte und politisch Verantwortlichen, deren Finanzierung, Verwaltung und Informationsaustausch bezüglich der Baumverwaltung und -erhaltung. Die Ergebnisse zeigen, dass die Bedeutung von Stadtbäumen weitläufig durch die Verantwortlichen erkannt wird. Sie glauben auch, dass urbane Bäume den Wert von Grundstücken erhöhen können und zum Stolz der Gemeinde beitragen können. Die Ökologischen Vorteile wurden dennoch eher unterbewertet. Die Städte in Alabama USA geben weniger als $\$ 60.000$ pro Jahr für Baumpflanzungen, Baumerhaltung und Beseitigung von Laub sowie Fällungen. Städte mit einer großen Population geben gewöhnlich mehr für Bäume aus, entsprechend haben höhere Haushaltseinkommen und niedrigere Armutsraten gehen mit höheren Ausgaben für Baumprogramme einher. Es wurden relativ wenige Unterschiede zwischen den drei Gruppen von Befragten: Verwaltungschefs, Ratsmitglieder und Administratoren gefunden. Die Ergebnisse zeigen, dass viele öffentliche Angestellte sich nicht bewusst sind oder darüber informiert, wie verbundene Agenturen einen Service zur urbanen Baumverwaltung beitragen.

Resumen. Utilizando datos de encuesta, este estudio exploró a empleados municipales de Alabama y la percepción de los responsables políticos de árboles urbanos, financiación, administración e información sobre gestión de bosque urbano. Los resultados sugieren que la importancia de los árboles urbanos es reconocida por las autoridades y empleados municipales locales. También creen que los árboles urbanos podrían aumentar el valor de la propiedad y promover el orgullo de la comunidad. Los beneficios ecológicos, sin embargo, fueron menos valorados. Las ciudades de Alabama en los Estados Unidos gastaron menos de USD $\$ 60.000$ por año en plantación de árboles, mantenimiento de árbol, escombros y eliminación. Las ciudades con una gran población parecen gastar más en árboles urbanos; asimismo, con mayores ingresos de los hogares y menores tasas de pobreza tendrían mayores gastos en programas de árbol urbano. Se encontraron diferencias relativamente menores entre los tres tipos de empleados y administradores: los administradores, alcaldes y miembros del Consejo. Los resultados indican que muchos funcionarios municipales no conocían o no estaban informados con relación a las agencias que proporcionan servicios de manejo del árbol urbano. 